\title{
Pituitary Gland Double Adenomas
}

National Cancer Institute

\section{Source}

National Cancer Institute. Pituitary Gland Double Adenomas. NCI Thesaurus. Code C154519.

Pituitary gland adenomas composed of two separate tumors with two different cell types in the same gland. (WHO 2017) 